\title{
Corrigendum: Phosphatidylinositol-3-OH kinase and nutrient-sensing mTOR pathways control T lymphocyte trafficking
}

Linda V Sinclair, David Finlay, Carmen Feijoo, Georgina H Cornish, Alex Gray, Ann Ager, Klaus Okkenhaug, Thijs J Hagenbeek, Hergen Spits \& Doreen A Cantrell

Nat. Immunol. 9, 513-521 (2008); published online 6 April 2008; corrected after print 19 May 2008

In the version of this article initially published, the key for Figure $5 \mathrm{~b}$ is incorrect. The black bars should be 'CD4 ${ }^{+} \mathrm{SP}$ ' and the gray bars should be 'DP'. The error has been corrected in the HTML and PDF versions of the article. 